\title{
Begonia wui-senioris (sect. Platycentrum, Begoniaceae), a new species from Myanmar
}

\author{
Ching-l Peng ${ }^{1 *}$, Hong Wang ${ }^{2}$, Yoshiko Kono ${ }^{1}$ and Hsun-An Yang ${ }^{1 *}$
}

\begin{abstract}
Background: The flora of Myanmar is under-collected compared with all other tropical Asian countries. An unknown Begonia was grown from seeds collected from a limestone hill in Central Myanmar, and compared with potentially allied species.

Results: The unknown Begonia is rhizomatous, has peltate leaves, 2-locular ovaries, and is evergreen. It is clearly assignable to sect. Platycentrum. Only two other species of Begonia, B. josephii and B. subperfoliata, in Myanmar have peltate leaves, but they are deciduous tuberous plants with 3-locular ovaries and belong to sect. Diploclinium.

Conclusions: Thorough studies of literature and herbarium materials support the recognition of a new species, Begonia wui-senioris, which is fully described and illustrated. Begonia wui-senioris has the lowest chromosome number $(2 n=14)$ for the genus.
\end{abstract}

Keywords: Begonia wui-senioris; Begoniaceae; Chromosome number; Limestone; Myanmar; New species; Sect. Platycentrum

\section{Background}

The most recent checklist for the Begonia of Myanmar (Hughes, 2008) reports 57 species as native. Almost concurrently, a new species was reported, Begonia hayamiana (sect. Sphenanthera) (Tanaka and Hughes 2007), bringing to the total to 58. In 2009, Hong Wang, the 2nd author of this article collected seeds of a Begonia from Central Myanmar and sent them to the senior author, Peng, who germinated them and raised them to maturity in the experimental greenhouse of Academia Sinica, where they were carefully examined. Upon consulting herbarium materials from major herbaria, both domestic and abroad, the plants were found not to belong to any species known from Myanmar. However, a herbarium specimen in E, collected from the region where our seeds were gathered, corresponds to our living material. That specimen was annotated in 1992 as "Begonia lacei C. Y. Wu, sp. nov. ined.," by the late Prof. Zhengyi Wu, renowned botanist of the Chinese Academy of Sciences. This unpublished taxon was excluded from the current checklist for Myanmar (Hughes 2008).

\footnotetext{
* Correspondence: bopeng@sinica.edu.tw; shin34tfg@gmail.com ${ }^{1}$ Herbarium (HAST), Biodiversity Research Center, Academia Sinica, Nangang, Taipei 115, Taiwan

Full list of author information is available at the end of the article
}

\section{Methods}

Materials

Living plants of Begonia wui-senioris were raised from seeds collected from ca. $200 \mathrm{~km}$ northeast of Mandalay, Myanmar and grown in an experimental greenhouse at Academia Sinica. The type collection (Peng 22199) was gathered from the greenhouse and deposited at HAST herbarium.

\section{Chromosome preparations}

Root tips of Begonia wui-senioris were pretreated with $2 \mathrm{mM}$ 8-hydroxyquinoline solution at $15-18^{\circ} \mathrm{C}$ for $6-$ $8 \mathrm{~h}$ and then fixed overnight in ethanol-acetic acid (3:1) below $4^{\circ} \mathrm{C}$. They were macerated in an enzyme mixture [2\% Cellulase Onozuka R-10 (Yakult Honsha, Tokyo, Japan) and 1\% Pectolyase (Sigma, St. Louis, $\mathrm{MO}, \mathrm{USA})]$ at $37^{\circ} \mathrm{C}$ for about $1 \mathrm{~h}$. Chromosomes were stained in 2\% Giemsa solution (Merck, Darmstadt, Germany). Classification of the chromosome complements, based on centromere position at mitotic metaphase, follows Levan et al. (1964).

\section{Cryo scanning electron microscopy}

Fresh leaves of Begonia wui-senioris were dissected and attached to a stub. The samples were frozen with liquid 
nitrogen slush, then transferred to a sample preparation chamber at $-160^{\circ} \mathrm{C}$ and etched for $15 \mathrm{~min}$ at $-85^{\circ} \mathrm{C}$. After etching, the temperature reached $-130^{\circ} \mathrm{C}$ for sample fracturing and coating. After coating, the samples were transferred to the SEM chamber and observed at $-160^{\circ} \mathrm{C}$ with a cryo scanning electron microscope (FEI Quanta 200 SEM/Quorum Cryo System PP2000TR FEI).

\section{Results and discussion}

Species description

Begonia wui-senioris C.-I Peng, sp. nov. (sect. Platycentrum). - Type: Myanmar. Ca. $200 \mathrm{~km}$ northeast of Mandalay, elevation ca. $200 \mathrm{~m}$, on limestone hill, 2 May 2009, specimens pressed from cultivated plants on 18 May 2011, Ching-I Peng 22199 (holotype: HAST; isotype: E). 曼德勒秋海棠 Figures 1 and 2.

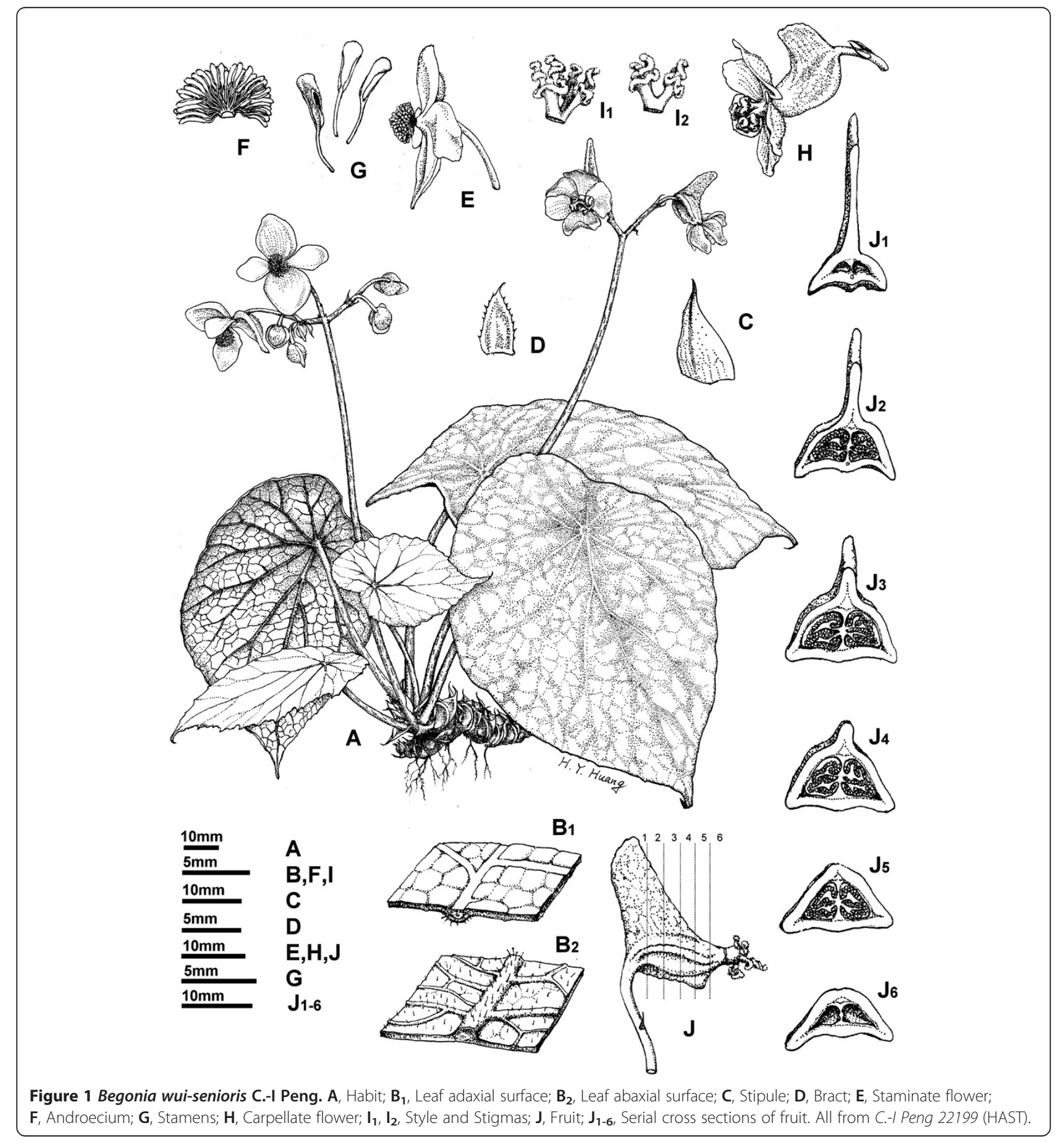




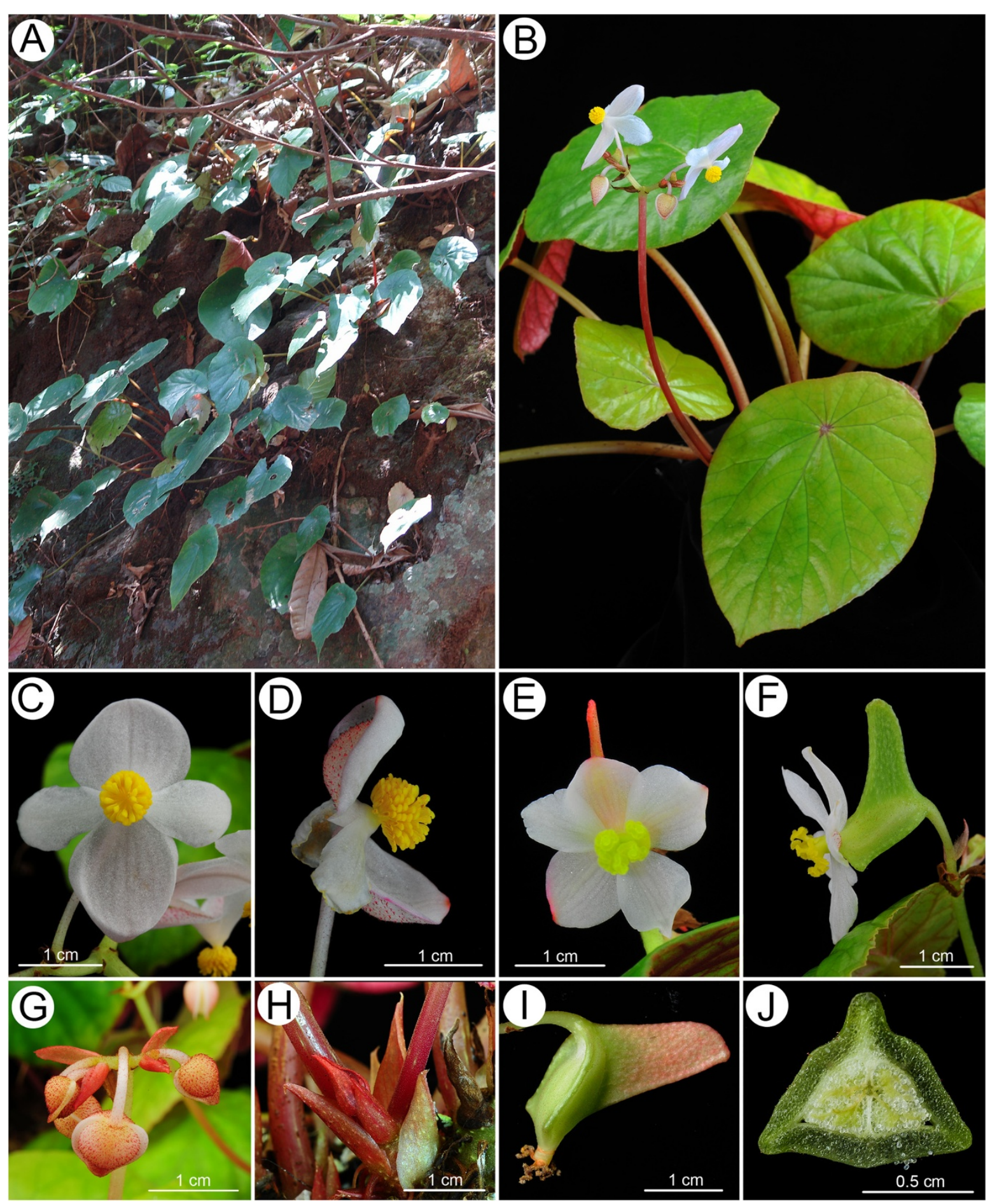

Figure 2 Begonia wui-senioris C.-I Peng. A, Habit and habitat; B, Cultivated plant at anthesis; C, Staminate flower, face view; D, Staminate flower, side view; E, Carpellate flower, face view; F, Carpellate flower, side view; G, Inflorescence and bracts; H, Stipules on rhizomes; I, Fruit; J, Cross section of fruit. All from C.-I Peng 22199 (HAST).

Herbs, monoecious, evergreen, rhizomatous. Rhizomes $1 \mathrm{~cm}$ thick, to $10 \mathrm{~cm}$ long, internodes ca. $0.5 \mathrm{~cm}$ long. Stipules eventually deciduous, ovate-triangular, boatshaped, ca. $1.2 \mathrm{~cm}$ long, $0.9 \mathrm{~cm}$ wide, apex attenuate.
Leaves peltate; petiole terete, $5-21 \mathrm{~cm}$ long, $0.2-0.5 \mathrm{~cm}$ across, green, nearly glabrous; leaf blade asymmetric, ovate, (4.5-)6.2-13(-14.8) cm long, (3-)5-8(-9.7) cm wide, apex acuminate, subcoriaceous, abaxially pale 
green or red, veins red and puberulous, adaxially green and glabrous. Inflorescences axillary, arising directly from rhizome, cymes dichasial, branched 2 or 3 times. Peduncle $6-25 \mathrm{~cm}$ long, $0.2 \mathrm{~cm}$ across, sparsely red puberulous or glabrous; bracts elliptic, $0.7 \mathrm{~cm}$ long, $0.3 \mathrm{~cm}$ wide, boat-shaped, red, sparsely ciliate, eventually deciduous. Staminate flowers: pedicel $1.7-2.3 \mathrm{~cm}$ long, red scabrous, tepals 4 , outer 2 ovate, broadly ovate or suborbicular, ca. $1.4 \mathrm{~cm}$ long, $0.9 \mathrm{~cm}$ wide, white, abaxially red scabrous, inner 2 elliptic, ca. $1.2 \mathrm{~cm}$ long, $0.7 \mathrm{~cm}$ wide, white; androecium actinomorphic, spherical, ca. $0.5 \mathrm{~cm}$ across; stamens 60-80; anthers oblong-obovoid, apex obtuse, 2-locular. Carpellate flower: pedicel 1.5-2 cm long, red scabrous, tepals 5, elliptic, $1.1-1.4 \mathrm{~cm}$ long, $0.8-1.2 \mathrm{~cm}$ wide, white, abaxially red scabrous; ovary trigonousellipsoid, ca. $1.7 \mathrm{~cm}$ long, $0.3 \mathrm{~cm}$ thick (wings excluded), red scabrous, unequally 3-winged, 2-locular; lateral wings inconspicuous, $0.2 \mathrm{~cm}$ tall, greenish, abaxial wing oblong-ovate, ca. $1.7 \mathrm{~cm}$ tall, reddish; placentae axile, bilamellate; styles 2 , fused at base, stigma spirally twisted. Capsules nodding, fruit body trigonous- ellipsoid, ca. $1.7 \mathrm{~cm}$ long, $0.3 \mathrm{~cm}$ thick (wings excluded), apex with persistent styles; abaxial wing trigonous to oblong-ovate, ca. $1.9 \mathrm{~cm}$ tall. Somatic chromosome number, $2 n=14$ (see below).

\section{Additional specimens examined}

Myanmar. Grown at Maymyo, from plant brought from Gokteik or Kadu Hill. J. H. Lace s. n., s. d., (E [E00265073]); upper Central Myanmar: Mandalay Division, Peitchin Myaung Pagoda, Pyin Oo Lwin. 6 July 2001. N. Tanaka, A. Tanaka, Than Than Aye \& Khin Myo Htwe 021482 (TI).

\section{Distribution}

Known only from central Myanmar (Figure 3). John Henry Lace first collected this species in the 1910s. It was purchased by the Royal Botanic Garden Edinburgh in 1918 after Lace's sudden death. To date, there are only three known collections of this species, all made near Mandalay.

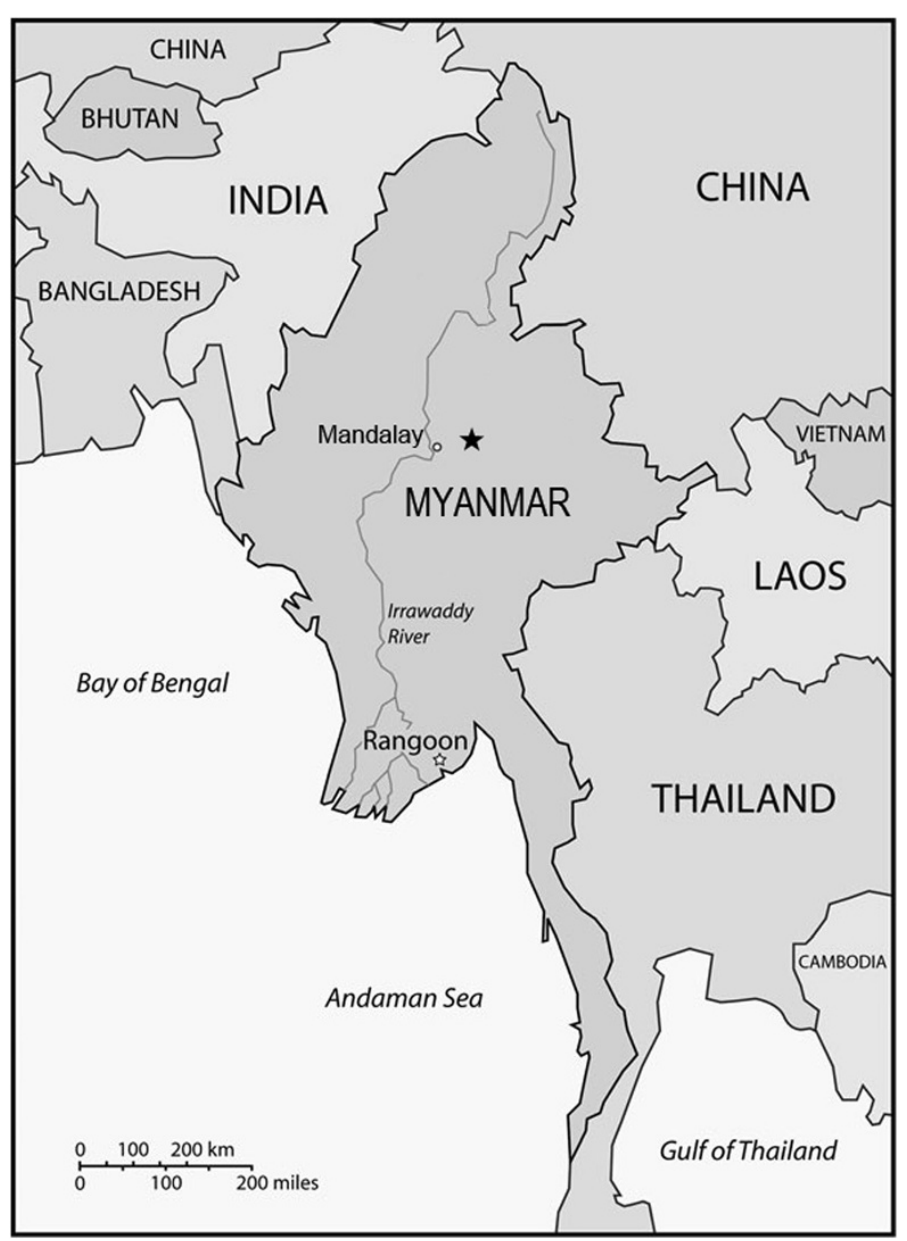

Figure 3 Distribution of Begonia wui-senioris $(\star)$ in Myanmar. 


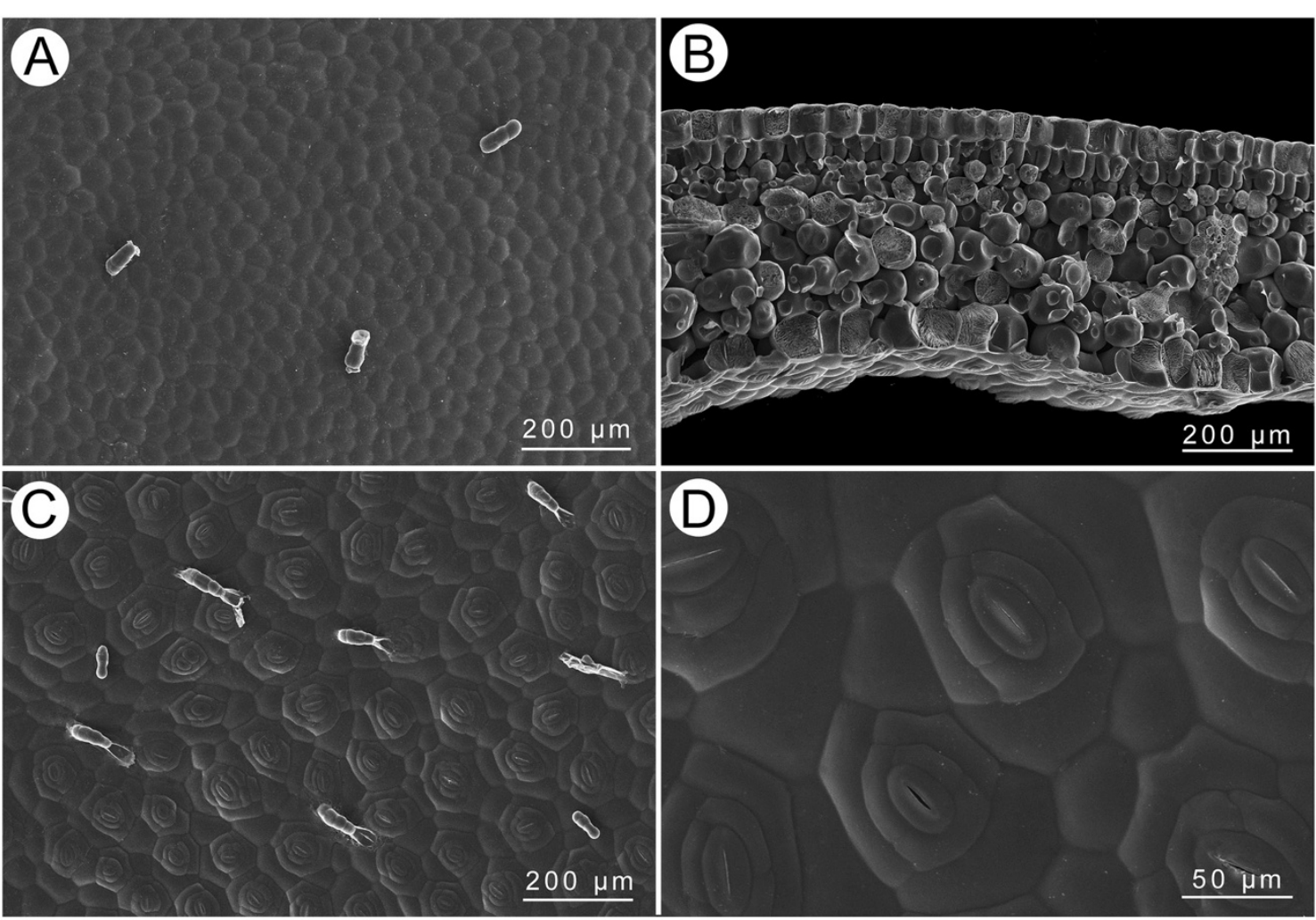

Figure 4 Leaf SEM microphotographs of Begonia wui-senioris. A, Adaxial surface, B, Cross section; C, Abaxial surface; D, Stomata complex.

\section{Habitat}

Lithophytic. Disturbed tropical rain forest; on limestone hills, on shaded, humid, rock surfaces near caves by waterfalls (based on Peng 22199).

\section{Phenology}

Flowering April to August; fruiting June to October.

\section{Etymology}

The specific epithet commemorates the late Prof. Zhengyi $\mathrm{Wu}$, a renowned Chinese botanist.

\section{Leaf anatomy}

Adaxial surface with scarce trichomes (Figure 4A); epidermis single-layered on both surfaces, hypodermis absent (Figure 4B); abaxial surface clothed with trichomes and very densely distributed stomata, stomata complex single, helicocytic, nearly flat (Figure 4C,D).

\section{Chromosome cytology}

Somatic chromosomes at metaphase of Begonia wuisenioris were determined to be $2 n=14$ (Figure 5), which is the first confirmed report of the lowest chromosome number known for the genus. Somatic metaphase chromosomes of most species of Begonia are nearly always small $(<2 \mu \mathrm{m}$ long), and karyotypes are mostly impossible

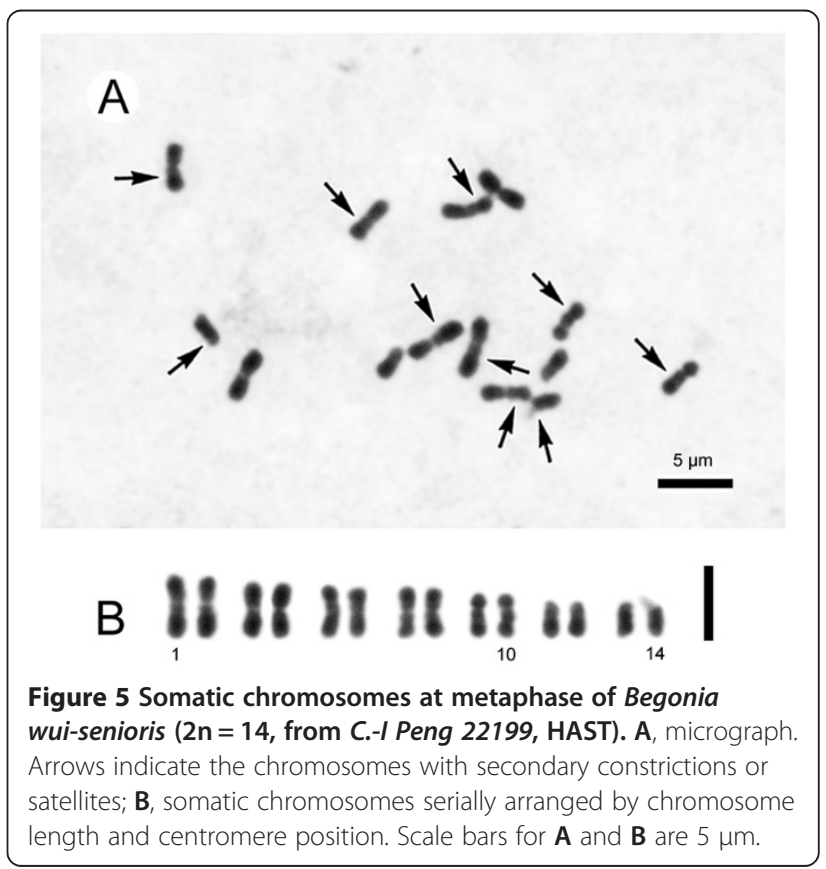


to be determined. Begonia wui-senioris, however, has longer chromosomes and its karyotype is fully described here. The 14 chromosomes gradually vary in length from ca. 2.2 to $4.2 \mu \mathrm{m}$ long. Among them, ten (Figure 5B: Nos. $1-8$, 11, 12), two (Figure 5B; Nos. 9, 10) and two (Figure 5B: Nos. 13, 14) chromosomes have the centromere in the median (m), submedian (sm) and subterminal (st) positions, respectively. Most chromosomes have secondary constrictions (SC) or satellites (sat): SCs are located at interstitial regions of the long arms in four $\mathrm{m}$ - (Figure 5B: Nos. 1, 2, 7, 8) and two sm-chromosomes (Figure 5B: Nos. 9, 10); at interstitial region of the short arms in two m-chromosomes (Figure 5B: Nos. 5, 6); satellites were observed in the distal regions of the short arms in two st-chromosomes (Figure 5B: Nos. 13, 14). The karyotypic formula of $B$. wui-senioris is therefore $2 n=14=$ $10 \mathrm{~m}^{6 \mathrm{SC}}+2 \mathrm{sm}^{2 \mathrm{SC}}+2 \mathrm{st}^{2 \mathrm{sat}}$.

Begonia section Platycentrum in Asia comprises about 110 species (Shui et al. 2002). To our knowledge, chromosome numbers of about 30 taxa have been reported for species in this section (e.g. Ye et al. 2004; Peng et al. 2006; Li et al. 2005). The karyotypes show wide variation in number, especially in Taiwanese Begonia (Oginuma and Peng 2002). Among the species belonging to sect. Platycentrum, $B$. wui-senioris is unique in having longer chromosomes and the lowest chromosome number $(2 n=14)$ for the genus. Nakata et al. (2003) documented a probable chromosome count of $2 n=$ ca. 14 for a sterile, not positively identified, plant from Yunnan, China.

\section{Notes}

Begonia wui-senioris, B. josephii and B. subperfoliata are the only three peltate-leaved species occurring naturally in Myanmar. The latter two, however, are deciduous, tuberous species with a single leaf and a 3-locular ovary and are classified within sect. Diploclinium.

\section{Conclusion}

Studies of literature and herbarium materials support the recognition of the new species, Begonia wui-senioris. This new species has the lowest chromosome number $(2 n=14)$ known for the genus.

\section{Competing interests}

The authors declare that they have no competing interests.

\section{Authors' contributions}

WH collected seeds of the new species, provided photographs of wild plants and field data; YK carried out the cytological study and karyotype analysis; HAY carried out the morphological observations and drafted earlier versions of the manuscript; CIP studied literature and herbarium materials and prepared the final version of the manuscript. All authors read and approved the final manuscript

\section{Acknowledgements}

We thank Dave Boufford (A/GH), Qiner Yang (IBSC) and Mark Hughes (E) for improving the manuscript; Han-Yau Huang (HAST) for the handsome line drawing of Begonia wui-senioris; Wann-Neng Jane (Academia Sinica) for guidance and technical assistance on Cryo Scanning Electron Microscopy; Wai-Chao Leong (HAST) for suggesting the resemblance between our living plant and the specimen E00265073 housed at E; Mark Hughes (E) for providing a high resolution photograph of the specimen E00265073; Peter H. Raven (MO), Nick Turland (B), Qiner Yang (IBSC) and Yun-Fei Deng (IBSC) for helpful discussions on the epithet of the new species. This study was supported in part by grants from the National Science Council and Academia Sinica,

Taiwan to Ching-l Peng (HAST).

\section{Author details}

${ }^{1}$ Herbarium (HAST), Biodiversity Research Center, Academia Sinica, Nangang, Taipei 115, Taiwan. ${ }^{2}$ Xishuangbanna Tropical Botanical Garden, Chinese Academy of Sciences, Mengla 666303, China.

Received: 18 October 2013 Accepted: 2 December 2013

Published: 1 February 2014

\section{References}

Hughes M (2008) An annotated checklist of Southeast Asian Begonia. Royal Botanic Garden Edinburgh, Edinburgh

Levan A, Fredga K, Sandberg AA (1964) Nomenclature for centromeric position on chromosomes. Hereditas 52:201-220

Li H-J, Ma H, Guan K-Y, Peng C-I (2005) Begonia rubinea (sect. Platycentrum, Begoniaceae), a new species from Guizhou, China. Bot Stud 46:377-383

Nakata M, Guan K-Y, Godo T, Lu Y-X, Li J-X (2003) Cytological studies on Chinese Begonia (Begoniaceae) I: chromosome numbers of 17 taxa of Begonia collected in 2001 field studies in Yunnan. Bull Bot Gard Toyama 8:1-16

Oginuma K, Peng C-I (2002) Karyomorphology of Taiwanese Begonia (Begoniaceae): taxonomic implications. J PI Res 115:225-235

Peng C-I, Leong W-C, Shui Y-M (2006) Novelties in Begonia sect. Platycentrum for China: B. crocea, sp. nov. and B. xanthina Hook., a new distributional record. Bot Stud 47:89-96

Shui Y-M, Peng C-I, Wu C-Y (2002) Synopsis of the Chinese species of Begonia (Begoniaceae), with a reappraisal of sectional delimitation. Bot Bull Acad Sin 43:313-327

Tanaka N, Hughes M (2007) Begonia (sect. Sphenanthera) hayamiana (Begoniaceae), a new species from northern Myanmar. Acta Phytotax Geobot 58(2/3):83-86

Ye H-G, Wang F-G, Ye Y-S, Peng C-I (2004) Begonia coptidifolia (Begoniaceae), a new species from China. Bot Bull Acad Sin 45:259-266

\section{doi:10.1186/1999-3110-55-13}

Cite this article as: Peng et al:: Begonia wui-senioris (sect. Platycentrum, Begoniaceae), a new species from Myanmar. Botanical Studies 2014 55:13.

\section{Submit your manuscript to a SpringerOpen ${ }^{\odot}$ journal and benefit from:}

- Convenient online submission

- Rigorous peer review

- Immediate publication on acceptance

- Open access: articles freely available online

- High visibility within the field

- Retaining the copyright to your article

Submit your next manuscript at $>$ springeropen.com 